\title{
ŠVIETIMO PASLAUGŲ KOKYBĖS VALDYMO VERTINIMAS. TĖVŲ POŽIŪRIS
}

\author{
Dalia Martišauskienė, Kęstutis Trakšelys \\ Klaipédos universitetas, Lietuvos edukologijos universitetas
}

\begin{abstract}
Anotacija
Straipsnyje autoriai tyrinejja švietimo paslaugų kokybės valdymo vertinimą tėvų požiūriu, nes tėvai, kaip ir vaikai, yra šių paslaugų vartotojai. Dažnai Lietuvoje manoma, kad švietimo paslaugos teikiamos tik vaikams, bet paslaugų teikimo ir gavimo sutartị su švietimo institucija pasirašo tėvai. Kita vertus, švietimo pagalbos specialistų paslaugų dalis skirta būtent tėvams. Tẻvų švietimas, švietimo institucijos bendravimas ir bendradarbiavimas taip pat vyksta su tèvais. Švietimo institucija be tèvų pagalbos nepajėgi išspręsti daugelio mokykloje kylančių ịvairaus pobūdžio problemų. Tad autoriai, apklausę 400 respondentų, pateikia tẻvų požiūrị ị švietimo kokybės paslaugas.
\end{abstract}

PAGRINDINIAI ŽODŽIAI: švietimo paslaugų kokybė, kokybės valdymas, vartotojai, tėvai.

\begin{abstract}
The authors of this article examine the evaluation of education service quality from parents' perspective, since parents as well as their children are the consumers of these service. Often there is a trend in Lithuania that education services are provided to children; even though, the service provision contract is signed between the education institution and parents. On the other hand, a part of services of specialists of education assistance are dedicated to parents. Moreover, parent education, cooperation and communication process is between the education institution and parents. The education institution is not able to solve most of the problems without the assistance of parents. Therefore, the authors present the point of view of 400 parents towards the quality of the provided education services.
\end{abstract}

KEY WORDS: Quality of education services, Quality management, Consumers, Parents.

\section{Ivadas}

Kokybès valdymas švietimo organizacijose laiduoja teikiamų švietimo paslaugų (edukacinių ir socialinių) efektyvumą, rezultatyvumą, naudingumą. Švietimo paslaugų kokybė ypač aktuali, nes jis nukreiptas į didelę žmonių grupę, t. y. tèvus ir vaikus, kurie atstovauja skirtingoms socialinėms grupėms ir turi ịvairių gebejjimų. Taigi suderinti ir išpildyti jų lūkesčius, norus, poreikius bei vykdyti švietimo institucijai deleguotas funkcijas nelengva, nes švietimo kokybė dažnai priklauso nuo išorès veiksnių (politinių, ekonominių ir socialinių). Todėl dažnai net pati švietimo sistema priversta reprodukuoti socialinę nelygybę, kuri kyla dèl anksčiau minètų veiksnių. Tai paradoksalu, nes teikiant švietimo paslaugas (edukacines ir socialines) siekiama sėkmingai ịtraukti ịvairių socialinių grupių atstovus į švietimo sistemos procesą, taip sušvelninant socialinę nelygybę, maži- 
nant skurdą ir socialinę atskirtį. Prieinama ir kokybiška švietimo sistema užtikrina paslaugų kokybę, vartotojų pasitenkinimą, aukštesnius pasiekimus, geresnius rezultatus, o tai laiduoja geresnị gyvenimą, socialinį mobilumą, suteikia atitinkamą statusą.

Straipsnio tikslas: atlikus empirinį tyrimą nustatyti, kaip vertinamas švietimo paslaugų kokybès valdymas.

Straipsnio objektas - paslaugų kokybės vertinimas.

Metodai: mokslinès literatūros analizè, leidžianti kontekstualizuoti švietimo paslaugų kokybės valdymo esmę, nustatyti tėvų, kaip paslaugų vartotojų, poreikius. Kiekybinio tyrimo metodai: švietimo ịstaigų paslaugų vartotojams (tėvams) taikyta anketa, kur pateikti uždarojo tipo klausimai. Siekta išsiaiškinti teikiamų švietimo paslaugų kokybės valdymo patirtį vartotojų populiacijoje ir paslaugos vartotojų poreikių tipologiją. Kiekybiniame tyrime (anketinėje apklausoje) dalyvavo 400 mokinių tèvų. Tyrimo imtis suformuota geografinio patogumo principu. Daugiapakopis tyrimas atliktas šiuose Lietuvos regionuose: Klaipedos, Telšių, Tauragès, Šiaulių ir Kauno.

Metodologinès tyrimo prieigos:

- Paslaugu kokybès valdymo teorija leidžia pagristi švietimo paslaugas kaip procesą, kurio turini ir vyksmą laiduoja vartotojo poreikiai, lūkesčiai bei tiekejjo ir vartotojo susitarimo dèl paslaugos kokybès galimybès. Švietimo paslaugos šiuo pagrindu gali būti grindžiamos ir kaip pagalba vartotojui, kai paslaugos teikèjas sąmoningai siekia ją transformuoti kaip vartotojui priklausanti produktą-gèrybę.

- Socialinio konstruktyvizmo teorija leidžia švietimo paslaugos kokybès valdymą grịsti teikèjų ir vartotojų požiūriu ị jiems svarbių žinių procesą, akcentuojant ankstesnio patyrimo reikšmę ir žinias pritaikant naujose situacijoje. Švietimo paslaugų kokybės valdymas gali būti suvokiamas per socialinio mokymosi procesus, kur išryškinamos individo adaptacijos visuomenèje galimybès, išmokstant jam (jiems) atlikti tam tikrus socialinius vaidmenis (paslaugos teikejų, vartotojų) bei konstruojant jų bendrą supratimą, kuris reiškia, kad tik turèdami aiškų tikslą ir atsižvelgdami ị švietimo situaciją bei ją lemiančius išorinius ir vidinius veiksnius jie gali ieškoti bendro sutarimo dèl švietimo paslaugų kokybès modeliavimo.

\section{1. İ vartotoją orientuotas paslaugų valdymas}

Švietimo organizacija, atsižvelgdama ị savo misiją, filosofiją, tikslus ir strategiją bei reaguodama ị visuomenès socialinius užsakymus, vaikų, tėvų vidinius poreikius, taip pat savo vidinị potencialą, yra ịgaliota teikti šias paslaugas: 


\section{Edukacines:}

- specialiųų poreikių turinčių vaikų ugdymo;

- socialinès atskirties integracijos;

- tèvų švietimo;

- profesinio orientavimo;

- pedagoginès-psichologinès pagalbos;

- individualizavimo;

- asmens ugdymo ir fizinių bei dvasinių galių plètojimo;

- švietimo pagalbos: psichologinę, specialiają pedagoginę, specialiają (mokytojo padèjèjo, gestų vertèjo), socialinę-pedagoginę (logopedo, spec. pedagogo, tiflopedagogo, surdopedagogo).

Socialines:

- vaikų teisių apsaugos;

- vaikų sveikatingumo;

- vaiko globos ir priežiūros;

- maitinimo;

- pavėžèjimo;

- prevencinio darbo.

Edukacines ir socialines paslaugas švietimo organizacijoje paprastai teikia: administracija, mokytojai, auklètojai, mokiniai ir specialistai. Pedagogai (auklètojos, mokytojai) atlieka svarbiausią vaidmenį, tenkindami vaikų poreikius, tiesiogiai sąveikauja su jais kiekvieną dieną. Sąveikaudami pedagogai, klasių auklètojai ir specialistai veikia vaikus. Pedagogai sudaro tiek mikro-, tiek mezoaplinkas, nes tiesiogiai sąveikauja su grupe / klase, kiekvienu vaiku, specialistais ir administracija.

Teikiamos edukacinès ir socialinès paslaugos turètų mažinti socialinę ịtampą tarp skirtingų socialinių grupių ir vienodai ị ugdymo bei ugdymosi procesą įtraukti visus mokinius, nepaisant jų gabumų ir socialines padèties. Anot R. Želvio (2002), švietimo organizacija turi prisiimti atsakomybę už tai, kas atsitinka jaunuoliams, kuriais ji rūpinasi. Todèl edukacinių ir socialinių paslaugų kokybė, anot H. Kemshall, R. Littlechild (2000) ir C. J. Titmus (1996), tiesiogiai priklauso nuo i̊staigos vadovų ir darbuotojų bendravimo su vaikais bei jų tėvais.

Švietimo sistemos socialinė funkcija, kaip visuomenès socialinès sistemos reprodukcija ir vystymas, dalyvavimas asmenybès socializacijos procese, apima du požiūrius ị teikiamas socialines paslaugas.

Plačiuoju požiūriu - socialinès paslaugos visuomenei: švietimo, sveikatos priežiūros, socialinès apsaugos, sporto, laisvalaikio, kultūros paslaugos. Detalesnis socialinių paslaugų apibrèžimas, akcentuojantis pastaraji požiūrị, pateikiamas A. Guogio (2000) ir Socialinès apsaugos terminų žodyne (2003), kuriame apibrèžiama, kad socialinés paslaugos - tai pagrindinių valstybès socialinio pobūdžio pro- 
gramų (socialinės apsaugos, mokymo ir užimtumo) vykdymo būdas bei socialinės apsaugos tarnybų teikiamos ne medicinos srities paslaugos.

Siauresniu požiūriu - socialinès paslaugos yra tokios paslaugos, kurias teikia socialinès apsaugos sistema, apimanti aštuonias socialines rizikas (ligą, neigalumą, senatvę, našlystę, šeimą / vaikus, nedarbą, būstą, socialinę atskirtį) pagal ES socialinès apsaugos statistikos klasifikaciją. Jos apima šias paslaugas: sveikatos priežiūros; ikimokyklinio ugdymo; asmens socialines paslaugas, teikiamas įvairiose socialinès globos įstaigose vaikams, seniems žmonėms, neịgaliesiems, rizikos grupių žmonèms; apgyvendinimo; iddarbinimo ir pajamų palaikymo. Atstovaudama pastarajam požiūriui, L. Žalimienè (2003) teigia, kad socialinių paslaugų terminas dažniausia vartojamas, kai kalbama apie valstybès pagalbą žmogui. Socialinių paslaugų kataloge (2000), kaip ir Lietuvos Respublikos socialinių paslaugų įstatyme (2006), socialinès paslaugos apibrěžiamos kaip tam tikros pagalbos asmenims suteikimas įvairiomis nepiniginėmis formomis bei globos pinigais, siekiant sugrąžinti gebejjimą pasirūpinti savimi ir integruotis ị visuomenę.

Švietimo organizacijos paslaugu teikimo vertinimas - daugialypis ir nenutrūkstamas procesas, reikalaujantis paslaugų teikejjo profesionalumo. C. Pollit ir kt. (2005) nurodo, kad kokybė neatsiejama nuo vertybių ir tikslų formulavimo, todèl kiekviena švietimo organizacija turi išsiaiškinti savo poreikius ir sukurti juos igyvendinančią strategiją, teikdama kokybiškas paslaugas vartotojams ir konkuruodama ugdymo srityje.

Taigi švietimo organizacijos gebejjimas sẻkmingai prisitaikyti prie nuolatinių pokyčių priklauso nuo švietimo organizacijos veiklos kokybės, gebẻjimo lanksčiai reaguoti ị paslaugų paklausą (Neifachas, 2004), jų funkcionalumą, efektyvumą ir rezultatyvumą.

Reikia pabrèžti, kad vienas pagrindinių demokratinès ugdymo institucijos požymių - jos narių nuomonės išklausymas ir atsižvelgimas ị ją bendruomenès valdymo procese, kuris akcentuoja dalyvavimą, siekiant didesnès ịtakos ir kontrolès (Beresford, Coft, 1993). Suprantama, kad švietimo organizacijos bendruomenè turi teisę būti išgirsta, dalyvauti švietimo organizacijos veikloje, apibrēžiant problemas ir imantis veiksmų joms spręsti. H. Kemshall, R. Littlechild (2000) tvirtina, kad ugdymo įstaigos socialinių paslaugų atitikimas šiandienos poreikiams tiesiogiai priklauso nuo įstaigos vadovų ir darbuotojų bendravimo su vaikų tėvais kaip vartotojais. Tẻvų socialinis dalyvavimas dažniausia siejamas su jų aktyvumu naudojantis socialinèmis paslaugomis, ypač edukacinėmis, ar gaunant pagalbą, paramą ir t. t. 


\section{2. Švietimo paslaugų kokybès vertinimas vartotojų (tėvų) požiūriu}

Tẻvams, kurių vaikai lanko švietimo įstaigas, buvo pateikti klausimai, siekiant išsiaiškinti, kaip jie vertina teikiamas švietimo paslaugas, kokių paslaugų pageidautų, kokie jų lūkesčiai dèl vaikų ugdymo kokybės gerinimo. Išanalizavę content analizès metodu teiginių turini, apibendrinome ir pateikème jų kategorijas ir subkategorijas. Pirmiausia tèvai atsakè ị klausimą: Kokiu švietimo paslaugu pasigendate?

Tèvų siūlymus dẻl pageidaujamų švietimo paslaugų apibūdina šešios kategorijos: Pagalbos vaikui specialistu paslangu teikimas; Meninio vaiku ugdymo paslangu teikimas; Sporto paslaugu teikimas; Užsienio kalbu mokymas; Savitarnos igūdžiu ugdymas; Užimtumo vasara paslauga.

Tèvų pageidaujamos paslaugos apima šias sritis: vaiko ugdyma (meninio, sportinio ugdymo, kalbu mokymo, savitarnos igūužiu lavinimo), specialistu pagalbos vaikams teikima ir vaiku užimtuma vasarą. Ugdymo srityje tèvams ypač svarbios yra meninio ugdymo paslaugos. Jie siūlo plètoti ugdymą visose meninio ugdymo srityse (choreografijos, muzikos, dailès, dramos). Be to, tèvai pageidautų neformaliojo vaikų ugdymo (būreliai) ir sportinès veiklos paslaugų. Jų nuomone, kai kuriuose darželiuose / mokyklose nesudarytos sąlygos vaikų sportinei veiklai, todèl jie nurodo sportinès veiklos galimybes lauke. Tèvai akcentuoja ir tokią sritị, kaip vaikų savitarnos ịgūdžių ugdymą, kuris svarbus ir namuose, ir švietimo ịstaigoje, nes ugdo savarankiškumą. Be to, tèvai siūlo užtikrinti vaikų užimtumą vasarą, taigi jų netenkina veiklos sezoniškumas, kai švietimo ịstaigos veiklos trukmė sutampa su vasaros atostogomis.

Plačiausiai atskleidžiama Meninio vaiku ugdymo paslangu teikimas kategorija (4 subkategorijos). Kitos dvi kategorijos: Pagalbos vaikui specialistu paslaugu teikimas ir Sporto paslaugu teikimas nurodytas siauriau (2 subkategorijos). Kategorijos: Užsienio kalbu mokymas, Savitarnos igūdžiu ugdymas, Užimtumo vasara paslanga. Šių paslaugų labiausiai pageidavo ikimokyklines įstaigas lankančių vaikų tèvai. Paskutinès 3 kategorijos visiškai neišplètotos, pateiktos deklaratyviai, pavieniais teiginiais, o tai rodo, kad tèvams yra mažiau reikšmingos nei anksčiau minètosios.

Plačiau apžvelgsime ir paanalizuosime išskirtas kategorijas:

- Kategorijos Meninio vaiku ugdymo ịvairove turini sudaro penkios subkategorijos: Choreografinio vaiku, Muzikinio vaiku ugdymo, Ugdymo daile, Ugdymo drama, Neformaliojo vaiku ugdymo paslaugos. Tèvų nuomone, švietimo ịstaigose per mažai dèmesio skiriama vaikų meniniam ugdymui, tai netenkina tèvų poreikių. Pagrindinè siūloma ugdymo forma yra neformalusis vaikų ugdymas, tai yra būrelių forma. Todèl jie siūlo, kad 
vaikai būtų mokomi šokio pradmenų (subkategorija Choreografinio ugdymo paslauga). Tèvų nuomonès dèl subkategorijos Muzikinio vaiku ugdymo paslauga rodo, kad reiketų ,papildomos muzikinès vaikų veiklos“ (2 teiginiai), chorinio dainavimo mokymo ir muzikos ugdymo būrelių. Subkategorijos Ugdymas daile turinys orientuotas ị dailès būrelius (3 teiginiai) ir keramikos mokymą. Tẻvai pageidauja papildomų meninės veiklos būrelių ar mokymų, tačiau jie nenurodo, kas juos turètų finansuoti: tai būtų papildoma paslauga, už kurią mokètų tėvai, ar užsièmimas, kurị finansuotų švietimo ịstaigos steigejjas.

- Kategorija Pagalbos vaikui specialistu paslaugu teikimas. Kaip ir pedagogai, vadovai, tėvai taip pat pastebi, kad jų vaikams ir jiems patiems reikètų psichologo (3 teiginiai) bei socialinio darbuotojo (1 teiginys) paslaugų. Šių paslaugų teikimo galimybes švietimo ịstaigoje vadovai turètų aptarti su steigèju. Jei nèra galimybès įsteigti psichologo etato visose įstaigose, reikètų bendradarbiauti su savivaldybès pedagogine-psichologine tarnyba ir šios tarnybos specialistai galètų teikti šią paslaugą.

- Kategorijos Veiksmingesnès sportinès veiklos vaikams organizavimas turinys orientuotas ị sportinès veiklos organizavimą lauke ir ị šios veiklos gerinimą (2 subkategorijos). Tèvams svarbios sportinio ugdymo paslaugos. Jie nurodo būtinybę plettoti šias paslaugas ir siūlo išeitị iš susidariusios situacijos - vaikų sportinę veiklą vykdyti lauke ari artimiausioje kiemo aplinkoje. Tèvų nuomone, ši paslauga turètų būti ịvairesnè ir patrauklesnè.

Paslaugų vartotojams (tėvams) buvo pateiktas klausimas: Kokie Jūsu lūkesčiai dèl švietimo paslaugu kokybès? Content analizès metodu išanalizuoti tėvų teiginiai ir pateiktos jų lūkesčių dèl ugdymo kokybės gerinimo kategorijos bei subkategorijos.

Tèvų lūkesčius dèl švietimo paslaugų kokybès gerinimo apibūdina devynios kategorijos: Pedagogu, vadovu ir kitu darbuotoju veiklos kokybé; Ugdymo turinio ir proceso kokybé; Priežiūros kokybé; Tarpusavio santykiu kokybé; Aplinkos estetika, atitikimas higienos reikalavimams; Sveikos gyvensenos kokybe, atitikimas vaiko norams; Vaiko rengimo mokyklai kokybé; Vaiku užimtumo kokybè. Pastebima, kad tèvai ypatingą dėmesị skiria darbuotojų (pedagogų, vadovų ir kt.) ir visos švietimo ịstaigos veiklos kokybei, kuri apima ne tik ugdymą, bet ir vadovavimą, darbuotojų veiklos kokybę, kvalifikaciją, tarpusavio santykius. Kokybišką ugdymą tèvai sieja ne tik su kompetencijų tobulinimu, bet ir su vaiko priežiūra, sveikatinimu, estetiška, higieniška aplinka. Tèvai nurodo ir tikisi, kad paslaugų teikejai yra orientuoti ị vaiko poreikių tenkinimą, kuris lemia vaiko norą lankyti ugdymo ịstaigą. Lūkesčiai dèl švietimo paslaugų kokybès siejami su pramogomis, užimtu$\mathrm{mu}$, galutiniu rezultatu, tai yra vaiko parengimu mokyklai. 
Kategorijos Pedagogu, vadovu ir kitu darbuotoju veiklos kokybe turinys ypač plačiai išplètotas. Jị sudaro penkios subkategorijos: Pedagogu veiklos kokybe; Pedagogu kvalifikacijos tinkamumas; Vadovu veiklos kokybé; Švietimo istaigos personalo veiklos kokybe; Pagalbos vaikui specialistu veiklos kokybe. Daugiausia dèmesio tèvai skiria subkategorijai Pedagogu veiklos kokybè (18 teiginių). Tèvai suvokia, kad siekiant vaikui teikti kokybiško švietimo paslaugas, labai svarbus kompetentingas, kvalifikuotas pedagogų darbas. Tèvai teigia, kad darželyje / mokykloje dirba „puikios, šaunios, geros auklètojos“. Tai leidžia daryti išvadą, kad tèvai yra patenkinti pedagogų veikla, kompetencija ugdant vaikus. Tẻvams svarbi ir pedagogu kvalifikacija. Subkategorijoje Pedagogu kvalifikacija tèvai nurodè, kad darželyje dirba „aukštos kvalifikacijos auklètojos“. Subkategorijoje Vadovu veiklos kokybé tėvai gerai ịvertino švietimo ịstaigų valdymą, tai rodo vadovų gebejjimas kompetentingai, kokybiškai vadovauti ịstaigai. Tèvams aktuali ne tik pedagoginio personalo darbo kokybè, bet ir specialistų bei aptarnaujančio personalo darbas. Jų teigimu, „visas kolektyvas darbštus, nuoširdus, rūpestingas, malonus“. Taigi galima teigti, kad tèvai yra patenkinti teikiamomis švietimo paslaugomis, vaiko ugdymo kokybe ir tai sieja su kokybišku švietimo įstaigos darbuotojų darbu.

Kategorijos Ugdymo turinio ir proceso kokybe turini sudaro šios subkategorijos: Žiniu, informacijos vaikui naudojimas; Ugdymo proceso organizavimo kokybé; Vaiko visapusiškas ugdymas. Tẻvams svarbu, kad „vaikas kasdien sužinotų ką nors naujo, gautų naujos informacijos“. Svarbi subkategorija Vaiko visapusiškas ugdymas. Atsižvelgiant ị tẻvų pateiktą nuomonę, galima manyti, kad tẻvams aktualus visapusiškas vaiko ugdymas, naujų žinių, kompetencijų igijimas, be to, jie tai sieja su viso personalo kokybiška veikla, gerais tarpusavio santykiais. Taigi tèvai suvokia, kad tik esant darniems tarpusavio santykiams, palankiam mikroklimatui vaikui ne tik teikiamos kokybiškos švietimo paslaugos, bet jie jaučiasi saugiai ir patogiai.

Kategoriją Aplinkos estetika, atitikimas higienos reikalavimams sudaro šios subkategorijos: Aplinkos estetika; Aplinkos estetika, atitikimas higienos reikalavimams. Tèvai akcentuoja, kad jiems svarbi švietimo ịstaigos ugdomoji aplinka, jos švara, tvarka, aplinkos estetiškumas, higiena (6 teiginiai). Tèvams aktualus ne tik vaikų ugdymas, bet ir graži, švari ugdomoji aplinka, kuri patogi ir vaikams, ir jų tèvams.

Kategorijos Sveikos gyvensenos turinys orientuotas ị kokybišką vaikų maitinimą ir sveiką gyvenseną. Atsižvelgdami ị šiuos tèvų lūkesčius, vadovai, pedagogai ir kiti darbuotojai turètų siekti, kad vaikai valgytų nustatytus mitybos reikalavimus atitinkantị maistą, nuolat būtų stebima ir stiprinama vaiko sveikata, diegiami sveikos gyvensenos pradmenys. 
Atlikus lūkesčių content analizę, galima daryti išvadą, kad tẻvai švietimo paslaugų kokybę sieja su ugdymo proceso organizavimu, žinių ir ịgūdžių perteikiamo turinio kokybe, t. y. su pačiu procesu, kuris turètų būti kūrybiškas. Tèvai orientuojasi ị galutini rezultatą - vaiko parengimą mokyklai ir ị kokybiškų sąlygų sudarymą ugdomojoje aplinkoje. Tẻvai, išsakydami lūkesčius dèl švietimo paslaugų kokybès gerinimo, orientuojasi ị vaiką, o ne ị save, kaip paslaugų vartotoją.

Tẻvų, kaip ir pedagogų bei švietimo ịstaigų vadovų, klausta, kas, jų nuomone, yra kokybè? Analizuojant tyrimo rezultatus faktorinès analizès pagrindinių komponenčių metodu, išskirti keturi švietimo paslaugų vartotojų (tėvų) kokybės sampratą apibūdinantys veiksniai: paslaugos naudingumas, tikslo atitikimas (23,9 proc. atsakymų sklaidos), tobulumas (23,6 proc. atsakymų sklaidos), atitikimas reikalavimams, paslaugu kokybès gerinimas (21,2 proc. atsakymų sklaidos), mažesniu sklaidos rodikliu (19 proc.) pasižymintis veiksnys - vartotoju poreikiai, paslaugos pokyčiai.

- Pirmaji veiksni - paslaugos naudingumas, tikslo atitikimas - lemia tai, kad tėvai, kaip ugdymo paslaugų vartotojai, apibrèždami kokybę, pirmiausia akcentuoja ekonomini jos naudingumą $(L=0,888)$ ir tikslo atitikimą $(L=0,816)$.

- Antrasis veiksnys atskleidžia, kad tėvai kokybės sampratą sieja su tobulumu $(L=0,883)$ ir klaidų nedarymu $(L=0,870)$.

- Trečiajị veiksni - atitikimas reikalavimams, kokybès gerinimas - apibūdina tai, kad ugdymo paslaugų vartotojai kokybę suvokia kaip paslaugų atitikimą reikalavimams $(L=0,979)$ ir nuolatini paslaugų kokybės gerinimą $(L=0,927)$.

Pastebima, kad tėvai, apibrěždami kokybės sampratą, akcentuoja ir vartotoju poreikiu tenkinima $(L=0,938)$ bei paslaugų pokyčius $(L=0,694)$, nors ši samprata reiškiasi silpniausiai. Faktorinès analizės rezultatai atskleide, kad švietimo paslaugų vartotojai kokybę pirmiausia suvokia kaip ekonominị paslaugos naudingumą, nors vartotojų poreikių tenkinimo ir paslaugų pokyčių su kokybės samprata jie nesieja. Galima daryti prielaidą, kad pokyčiai, vykstantys ugdymo ịstaigoje, juos menkai domina. Kaip ir atliekant kokybinio tyrimo (content) analizę, tèvai išskiria paslaugų tinklo plètojimą, t. y. mano, kad būtina atkreipti dẻmesị ị meninį, sportinį vaikų ugdymą, vaikų savitarnos bei užsienio kalbų mokymą (ikimokyklinio ugdymo įstaigose). Be to, tèvai pageidauja papildomų paslaugų, kurios susijusios su specialistų pagalba vaikui ir turi įtakos vaikui, kaip ugdymo proceso dalyviui.

Analizuojant kiekybinio tyrimo rezultatus, kai respondentu prašyta ịvertinti kokybės vadybos sistemą paslaugų vartotojų (tėvų) požiūriu, faktorinės analizès pagrindinių komponenčių metodu išskirti šie veiksniai: kliento poreikiai, darbo efektyvumas, materialine bazè, veiklos tobulinimas, paslaugu kokybe (57,8 proc. 
atsakymų sklaidos) ir mažesniu sklaidos rodikliu (23 proc.) pasižymintis veiksnys - ugdymo proceso gerinimas.

- Pirmasis veiksnys - kliento poreikiai, darbo efektyvumas, materialine bazé, veiklos tobulinimas, paslaugu kokybe - atskleidžia, kad kokybės vadybos sistema paslaugų vartotojams (tėvams) yra reikšminga, siekiant tikslingai nustatyti jų poreikius ( $L=0,917)$, didinti pedagogų darbo efektyvumą ( $L=0,897)$, gerinti materialinę bazę $(L=0,838)$, tobulinti vadovų veiklą $(L=0,788)$; mažiau reikšminga - teikiamų paslaugų kokybei $(L=0,699)$.

- Mažiau reikšmingas veiksnys - ugdymo proceso gerinimas - rodo, kad įstaigos kokybės vadybos sistema, tèvų nuomone, turi įtakos ugdymo proceso gerinimui $(L=0,881)$.

Remiantis tyrimo rezultatais, galima daryti prielaidą, kad tėvai, kaip švietimo įstaigos paslaugų vartotojai, pirmiausia kokybės vadybos sistemą sieja su savo, kaip vartotojų, poreikių tikslingu nustatymu, pedagogų darbo efektyvumu ir tik tada - su ugdymo proceso gerinimu.

Vertinant švietimo ịstaigos kokybès vadybos sistemai būdingus bruožus paslaugų vartotojų požiūriu, faktorinės analizès pagrindinių komponenčių metodu išskirti du veiksniai: kliento poreikiai, paskirties ir misijos realizavimas, ištekliu panaudojimas (49,9 proc. atsakymų sklaidos); reglamentuota sistema, ugdymo tobulinimas, veiklos atitikimas reikalavimams (34,5 proc. atsakymų sklaidos).

- Pirmasis veiksnys - kliento poreikiai, paskirties ir misijos realizavimas, ištekliu panaudojimas - atskleidžia tai, kad, remiantis švietimo įstaigos paslaugų vartotojų nuomonemis, kokybės vadybos sistemai būdingi bruožai yra kokybiškas ugdymo institucijos paskirties ir misijos realizavimas ( $L=0,946)$, klientų poreikių ir lūkesčių patenkinimas $(L=0,896)$, racionalus išteklių (finansinių, materialinių ir žmogiškųjų) naudojimas $(L=0,823)$.

- Antrasis veiksnys atskleidžia, kad tėvai, kaip švietimo paslaugų vartotojai, kokybès vadybos sistemai būdingus bruožus įvardija kaip griežtai reglamentuotą, dokumentuotą, kontroliuojamą sistemą $(L=0,931)$, nuolatinị vaiko ugdymo tobulinimą $(L=0,764)$ ir veiklos atitikimą nustatytiems reikalavimams $(L=0,698)$.

Remiantis visuotinès kokybès vadybos idejomis, organizacijos santykiai su vartotojais grindžiami glaudžiais ryšiais ir tarpusavio pasitikejjimu, todèl organizacija siekia žinoti ir tenkinti jų lūkesčius. Švietimo įstaigos paskirų vartotojų grupių lūkesčiai skiriasi asmeninėmis nuostatomis, socialiniais ir ekonominiais aplinkos procesais.

Faktorinès analizès pagrindinių komponenčių metodu išskirti trys tėvų, kaip švietimo paslaugų vartotojų, suvokimą lemiantys veiksniai: informacinès-komunikacinés, sveikatingumo paslaugos (35,1 proc. atsakymų sklaidos); socialinés pa- 
slaugos, bendruomenè nariai (22,4 proc. atsakymų sklaidos); švietimo, kultūrinèsrekreacinés paslaugos ( 21,8 proc. atsakymų sklaidos).

- Pirmasis veiksnys - informacinès-komunikacinès, sveikatingumo paslaugos - atskleidžia, kad švietimo ịstaigose tẻvai, kaip vartotojai, naudojasi pedagogų teikiamomis informacinèmis-komunikacinėmis paslaugomis $(L=0,969)$, priima sprendimus dèl galimybès pasirinkti mokyklą ar būtinybės vaiką leisti ị vaikų darželị $(L=0,888)$, tačiau rečiau naudojasi vaikams teikiamomis sveikatinimo $(L=0,653)$ ir visomis kitomis paslaugomis ( $L=0,631)$, jie gali švietimo ịstaigai teikti pasiūlymus $(L=0,627)$.

- Antrasis veiksnys apima teiginius, kurie atskleidžia tėvų naudojimąsi pedagogų teikiamomis socialinèmis paslangomis.

- Trečiasis veiksnys atskleidžia, kad tèvai, kaip švietimo paslaugų vartotojai, naudojasi pedagogų teikiamomis švietimo ir ugdymo $(L=0,929)$ bei kultūrinèmis-rekreacinèmis paslaugomis, dalyvaudami šventėse, išvykose, renginiuose ir kt. $(L=0,865)$.

Tẻvų įtraukimas ir dalyvavimas ugdymo institucijos veikloje - tai nuolatinis komunikacijos procesas, apimantis akademinị mokymą(-si) ir kitas mokyklos veiklas, nes tèvai turi būti visateisiai vaikų ugdymo partneriai, vaidinti pagrindinị vaidmenį vaikų ugdymo procese ir būti skatinami aktyviai ịsitraukti ị mokyklos gyvenimą.

Švietimo įstaigų praktika rodo, kad tèvai kokybès valdymo procesuose dažniausia dalyvauja per savivaldos institucijas: kuria veiklos programas, padeda planuoti švietimo politiką, teikia pasiūlymus dèl ịstaigos valdymo tobulinimo ir teikiamų paslaugų kokybės gerinimo, nes tèvus ir pedagogus sieja pagrindinis tikslas - vaiko gerovè. Vaikas kryptingai ugdomas tada, kai darniai sutaria šeima ir švietimo ịstaiga, kai vaikų ugdymas šeimoje ir švietimo ịstaigoje vienas kitą papildo (Litvinienè, 2000).

Tẻvų dalyvavimo švietimo ịstaigos kokybès valdymo procesuose būdų ir galimybių kriterijaus vidinei struktūrai ištirti pasitelktas faktorinès analizès metodas. Faktorinės analizės pagrindinių komponenčių metodu išskirti du tẻvų dalyvavimo ịstaigos kokybès valdymo procesuose veiksniai: individualūs pasiūlymai susirinkimu metu ir dalyvaujant tarybos veikloje (47,6 proc. atsakymų sklaidos); mažesniu sklaidos rodikliu (29,5 proc.) pasižymintis veiksnys - sprendimai dalyvaujant komisiju veikloje.

- Pirmasis veiksnys - individualūs pasiūlymai susirinkimu metu ir dalyvaujant tarybos veikloje - atskleidžia, kad tèvai dalyvauja švietimo įstaigos kokybės valdymo procesuose susirinkimuose teikdami pasiūlymus $(L=0,960)$, individualiai reikšdami savo nuomonę $(L=0,839)$, rečiau dalyvaudami švietimo ịstaigos tarybos veikloje $(L=0,760)$. 
- Antraji veiksni - sprendimai dalyvaujant komisiju veikloje - lemia tai, kad tèvai dalyvauja ịstaigos kokybès valdymo procesuose reikšdami nuomonę ir priimdami sprendimus $(L=0,900)$ bei dalyvaudami įvairių komisijų veikloje $(L=0,744)$.

Remiantis tyrimo rezultatais galima teigti, kad tèvai dalyvauja švietimo ịstaigos kokybės valdymo procesuose dažniausia teikdami pasiūlymus ir reikšdami individualią nuomonę per susirinkimus. Tačiau pasigendama didesnio tėvų aktyvumo ir iniciatyvos dalyvaujant švietimo ịstaigos tarybos ar įvairių komisijų veikloje, nors pastaruoju metu kokybės valdymas vis dažniau siejamas su savivalda, kai dalis valdymo funkcijų patikima ugdymo institucijų bendruomenėms ar jų atstovams.

Pedagogų bendravimas su tèvais jau buvo įvardytas kaip esminis elementas, igalinantis užtikrinti švietimo įstaigos teikiamų paslaugų kokybę, efektyvų ịstaigos funkcionavimą ir tinkamą bei tikslingą tẻvų informavimą apie vaiko vystymąsi ir ugdymą(-si). Siekiant visapusiškai atskleisti pedagogų ir tėvų bendradarbiavimo kokybę lemiančius veiksnius, palyginimui pateikiamas ịstaigos pedagogų ir tėvų bendradarbiavimo kokybę lemiančių veiksnių tėvų / globejų požiūriu vertinimas.

Faktorinès analizès pagrindinių komponenčiu metodu išskirti trys vaikų pedagogų ir tèvų bendradarbiavimo kokybę lemiantys veiksniai: tévu ịtraukimas $i$ švietimo įstaigos veikla, geranoriškas bendravimas, tèvu bendradarbiavimas tarpusavyje (25,8 proc. atsakymų sklaidos); renginiai tévams, tèvu informavimas ir konsultavimas (25,6 proc. atsakymų sklaidos); tèvu skatinimas ir domejjimasis vaiko šeima (22,6 proc. atsakymų sklaidos).

- Pirmasis veiksnys - tèvu ịtraukimas i švietimo ịstaigos veikla, geranoriškas bendravimas, tèvu bendradarbiavimas tarpusavyje - atskleidžia, kad vieni svarbiausių pedagogų ir tèvų bendradarbiavimo kokybę lemiančiu veiksnių, tèvų nuomone, yra šie: geranoriškas pedagogų bendravimas su tèvais $(L=0,904)$; nuolatinis tèvų ịtraukimas ị ịstaigos veiklą, kviečiant tẻvus dalyvauti grupės veikloje, šventėse ir kt. renginiuose $(L=0,903)$; tėvų supažindinimas su vaikų ugdymo, sveikatinimo ir kitais klausimais $(L=0,807)$.

- Antraji veiksni - renginiai tévams, tèvu informavimas ir konsultavimas apibūdina tai, kad pedagogų ir tėvų bendradarbiavimo kokybę, tėvų požiūriu, apibūdina tokios pedagogų atliekamos veiklos: jie organizuoja tėvams renginius noredami susipažinti $(L=0,903)$; nuolat konsultuoja tèvus jiems aktualiais klausimais $(L=0,874)$; atsako ị visus tèvams rūpimus klausimus $(L=0,823)$, nors ne visada informuoja tèvus apie vaikų ugdymosi pasiekimus $(L=0,677)$ ir pataria, nukreipia pas pagalbos vaikui specialistus, jei to reikia $(L=0,648)$. 
- Trečiasis veiksnys apima teiginius, kurie atskleidžia tèvu skatinima ir domejimasi vaiko šeima, kaip vieną iš pedagogų ir tèvų bendradarbiavimo kokybę lemiančių veiksnių. Faktorinès analizės rezultatai atskleidè, kad tèvai skatinami jaustis reikalingi švietimo ịstaigos veikloje $(L=0,900)$; geriau atlikti tėvų funkcijas $(L=0,739)$; kviečiami padirbèti ir pabūti grupejje $(L=0,721)$.

Vertinant pedagogų ir tėvų bendradarbiavimo kokybę lemiančius veiksnius, pastebėtina, kad vienas reikšmingiausių veiksnių, lemiančių šio proceso sėkmę, yra tèvų geranoriškas bendravimas ir dalyvavimas institucijos veikloje. Moksliniame kontekste pateikiamos ịvairios tèvų ịtraukimo ị bendradarbiavimo procesus formos ir būdai, tikslinga išsiaiškinti efektyviausius tèvų įtraukimo ị bendradarbiavimo procesus būdus bei galimybes.

Remiantis tėvų nuomonèmis, faktorinès analizès pagrindinių komponenčių metodu išskirti trys tèvų ịtraukimo ị bendradarbiavimo procesus veiksniai: pagalba tèvams ir ju dalyvavimas grupés veikloje (40,4 proc. atsakymu sklaidos); informacijos ir metodiniu priemoniu teikimas tèvams, ju nuomonès išreiškimas $(27,8$ proc. atsakymų sklaidos); mažesniu sklaidos rodikliu pasižymintis veiksnys - tèvų reikšmingumas (17,2 proc. atsakymų sklaidos).

- Pirmasis veiksnys - pagalba tèvams ir ju dalyvavimas grupès / klasès veikloje - atskleidžia, kad tèvams vienas reikšmingiausių jų ịtraukimo ị bendradarbiavimo procesus būdų yra tai, kad jie visada gali kreiptis ị švietimo ịstaigos specialistus $(L=0,908)$ ir įstaigos vadovą, taip patenkinami tẻvų poreikiai $(L=0,908)$; jie gali dalyvauti grupès / klasès veikloje $(L=0,893)$; yra geranoriškai sutinkami $(L=0,753)$.

- Antraji veiksni - informacijos ir metodiniu priemoniu teikimas tévams, ju nuomonés išreiškimas - lemia tai, kad, siekiant tèvus ịtraukti ị bendradarbiavimo procesus, jie visada supažindinami su naujausia informacija ( $L=0,845)$, gali naudotis pedagogine, metodine literatūra $(L=0,835)$, nors ne visada gali reikšti savo nuomonę vadovams, pedagogams, kitiems specialistams $(L=0,671)$.

- Trečiasis veiksnys atskleidžia, kad tėvai, remiantis jų nuomonèmis, visada jaučiasi darželyje / mokykloje reikšmingi $(L=0,931)$, tačiau tai yra silpniausias tèvų įtraukimą ị bendradarbiavimo procesus lemiantis būdas.

Kompleksinès pagalbos vaikui ir jo šeimai principas ịpareigoja švietimo institucijas derinti paslaugų teikimo kompleksiškumą, skirti dèmesį ne tik edukacinèms paslaugoms, bet ir plètoti aktyvios socialinès paramos šeimoms politiką, stiprinant veiksmingą socioedukacinę pagalbą vaikams bei jų tẻvams, skatinančią jų motyvaciją ir atsakomybę, socialinę partnerystę su ugdymo ịstaigomis, siekiant įveikti socialinę atskirti. 
Vertinant švietimo įstaigos teikiamų socialiniu paslangu kokybę tėvų požiūriu, faktorinès analizės pagrindinių komponenčiu metodu išskirti du veiksniai: socialine parama ir vaiko priežiūra (52,7 proc. atsakymų sklaidos); vaiku sveikatinimas ir teisiu apsauga (33,2 proc. atsakymų sklaidos).

- Pirmasis veiksnys - socialine parama ir vaiko priežiūra. Faktorinès analizès rezultatai atskleide, kad, tèvų nuomone, kokybiškiausios švietimo ịstaigoje socialinès paslaugos yra: specialiujų poreikių vaikų ugdymas $(L=0,968)$; socialinès atskirties integracija $(L=0,968)$; maitinimas $(L=0,910)$; vaiko globa ir priežiūra $(L=0,883)$.

- Antrasis veiksnys - vaiku sveikatinimas ir teisiu apsauga - atskleidžia, kad ir tėvai akcentuoja vaikų sveikatinimo paslaugas $(L=0,935)$; vaikų teisių apsaugą $(L=0,832)$; sveikos gyvensenos ugdymą $(L=0,823)$.

Galima teigti, kad šeimos per mažai informuojamos ir konsultuojamos, trūksta informacijos apie teikiamas švietimo paslaugas, ypač kaimo vietovėse. Šeimos, neturėdamos informacijos, negali pasinaudoti jau esamomis švietimo galimybèmis, todèl numatyta steigti daugiafunkcius centrus, diegti naujus švietimo pagalbos teikimo modelius, siekiant patenkinti visuomenès informacinius poreikius. Tai atskleidžia, kad švietimo institucijose reikšmingos tampa informacinės-komunikacinès paslaugos, kurios ịgalina glaudesnị šeimų ir ugdymo institucijų bendravimą bei bendradarbiavimą, užtikrina efektyvesnį tèvų ịsitraukimą $\mathfrak{i}$ švietimo ịstaigos veiklą ir vaikų ugdymo(-si) procesus.

Faktorinès analizės rezultatai atskleidè, kad, tėvų nuomone, švietimo ịstaigose kokybiškai teikiamos informacinès-komunikacinès paslaugos yra šios: informacijos apie vaiko ugdymą ir pasiekimus teikimas $(L=0,967)$; informacijos apie ịstaigos veiklą teikimas $(L=0,967)$; specialistų teikiama informacija $(L=0,947)$; gebejjimas išklausyti tèvus $(L=0,862)$.

Vertinant teikiamų kultūrinių-rekreaciniu paslangu kokybę tėvų požiūriu, faktorinès analizès pagrindinių komponenčių metodu išskirtas vienas veiksnys, apibūdinantis jų kokybę: kultūrinès-rekreacinès paslaugos (65,8 proc. atsakymų sklaidos).

Kultūrinių-rekreacinių paslaugų veiksnys apima teiginius, kurie ịvardija, tėvų požiūriu, švietimo ịstaigoje kokybiškai teikiamas kultūrines-rekreacines paslaugas: renginių, švenčių organizavimas $(L=0,821)$; išvykų, ekskursijų organizavimas $(L=0,808)$; laisvalaikio organizavimas $(L=0,804)$.

Pastaruoju metu didelis dėmesys skiriamas švietimo ịstaigu gebejjimams teikti ne tik švietimo, socialines, informacines, bet ir specialiosios pagalbos vaikui paslaugas. Specialiosios pagalbos paskirtis - nustatyti vaikų specialiuosius ugdymosi poreikius ir juos tenkinti, užtikrinti palankias jų ugdymosi sąlygas, ugdyti pedagogų, tèvų / globẻjų gebejjimą ugdyti šiuos vaikus, didinant jų ugdymosi veiks- 
mingumą. Specialiąą pagalbą ịstaigoje teikia medicinos darbuotojai, logopedas, specialusis pedagogas, tiflopedagogas, surdopedagogas, judesio korekcijos ir kiti specialistai tiems vaikams, kuriems jos reikia.

Vertinant specialiosios pagalbos vaikui kokybę švietimo įstaigoje tėvų požiūriu, nagrinèta dirbančiu specialistų (medicinos darbuotojo, logopedo, psichologo, spec. pedagogo) veiklos kokybė. Faktorinès analizės pagrindinių komponenčiu metodu išskirtas vienas veiksnys, apibūdinantis specialiosios pagalbos vaikui kokybę: specialistų teikiamų paslaugų kokybė (68,3 proc. atsakymų sklaidos).

Faktorinès analizès rezultatai atskleidè, kad, tèvų nuomone, švietimo ịstaigoje kokybiškiausiai specialiąsias paslaugas vaikams teikia medicinos darbuotojas ( $L=0,932)$; logopedas, $(L=0,899)$; psichologas $(L=0,781)$, nors spec. pedagogo teikiamos paslaugos, tèvų nuomone, yra nepakankamai kokybiškos $(L=0,668)$.

\section{Išvados}

Atlikus empirinị tyrimą nustatyta: tėvų, kaip švietimo paslaugų vartotojų, požiūriu, kokybiškiausios edukacinès paslaugos yra vaiko rengimas mokyklai (darželiuose) ir gyvenimui (mokyklose), vaikų etnokultūros ir sveikatingumo ugdymas; socialinés paslangos - specialiujų poreikių vaikų ugdymas, socialinès atskirties integracija (ịtraukusis ugdymas), vaiko maitinimas, priežiūra ir globa; informacinés-komunikacinés paslaugos - informacijos apie vaiko ugdymą, pasiekimus ir ịstaigos veiklą tėvams teikimas; kultūrinès-rekreacinès paslaugos - renginių, švenčių, išvykų, ekskursijų vaikams organizavimas; specializuotos pagalbos vaikams teikimo paslaugos - medicinos darbuotojo, logopedo ir psichologo paslaugos.

Tėvai suvokia ugdomosios aplinkos vaidmenị ir reikšmę vaikų asmenybės raidai. Jų teigimu, švietimo ịstaigoje ugdomoji aplinka atitinka vaikų amžių ir poreikius, kuriamas palankus mikroklimatas grupejje. Tèvus dažniausia tenkina švietimo įstaigos teritorija, vaikų užimtumui ir ugdymui skirtos patalpos išdėstytos tinkamai ir t. t.

Reikšmingiausias veiksnys, lemiantis pedagogų ir tėvų bendradarbiavimo kokybę tiek paslaugos teikejjams, tiek vartotojams yra geranoriškas tėvų bendravimas ir dalyvavimas institucijos veikloje, pedagogų teikiama informacija ir patarimai tèvams. Veiksmingiausi tèvų ịtraukimo ị bendradarbiavimo procesą būdai yra darželio specialistų ir vadovų pagalba jiems, galimybė dalyvauti grupès veikloje.

Tẻvų apsisprendimą pasirinkti konkrečią ikimokyklinio ugdymo įstaigą lemia geras jos įvaizdis visuomenèje ir kokybiškai teikiamos ugdymo paslaugos. 


\section{Literatūra}

Beresford, P., Coft, S. (1993). Citizen Involvement: A Practical Guide for Change. London: Macmillan.

Guogis, A. (2000). Socialinés politikos modeliai. Vilnius: Eugrimas.

Kemshall, H., Littlechild, R. (2000). User involvement and Participation in Social Care. London and Phuladelphia: Jessica Kingsley Publishers.

Socialinès apsaugos terminuz žodynas. (2000). Vilnius: Sveikatos ekonomikos centras.

Neifachas, S.(2004). Ikimokykliniu įstaigu vadyba:teorija ir praktika. Vilnius: UAB Ciklonas.

Pollit, C., Bouckaert, G., Loffler, K. (2005). Quality Journeys in the European Public. Sector: From thrre, to hers, to Where. Quality Journeys in the European Public Sector.

Titmus, C. J. (1996). Adult Education: Concepts and Principles. The International Encyclopedia of Adult Education and Training. Second Edition. Oxford: Pergamum Press.

Žalimienè, L. (2003). Socialinès paslaugos. Vilnius: VU specialiosios psichologijos laboratorija.

Želvys, R. (2002). Švietimo sistemos tobulinimas. Gamintojai, vartotojai, teikejjai ir švietimo paslaugu kokybė. Acta Paedagogica Vilnensia, Nr. 9, p. 303-310.

\section{EDUCATION QUALITY MANAGEMENT EVALUATION: PARENTS' ATTITUDE}

\section{Dalia Martišauskienė, Kęstutis Trakšelys}

\section{Summary}

In order to assess comprehensively the system of quality management of education, in the research, not only the services providers, but also the consumers (parents) are used for the purpose of investigation. On the basis of the method of questionnaire, the services consumers' (parents) viewpoint to the system of quality management and consumers was revealed, i.e. their knowledge related to the conception of quality and management was revealed; the functions of quality management; the features of quality management system that are characteristic to the institution of education were identified; parents' needs as services consumers of education were ascertained; the means that enable the latter to take part in the quality management processes of institution.

After the assessment of parents' opinion, it is possible to state that the consumers conceive the quality as an economical usefulness of the services though they do not relate the requirements of the consumers' needs to the conception of quality. The consumers (parents) of education services see the close interaction of the functions determining the quality management (planning, organization, motivation, coordination, and control), only the motivation and organization, according to their opinion, are not enough correlated in management functions in education 
institution. In accordance to the viewpoint of the parents as service consumers of education, the essential constituents of management conceptions is the observance of the rules of law while properly implementing strategic decisions and envisaging the direction.

On the basis of the research results, it is possible to state that the services consumers (parents) of education relate the system of quality management of institution to their as consumers' requirements purposeful establishment, educators' work efficiency as well as they emphasize those features characteristic to the system of quality management.

On the grounds of the research results, it is possible to presume that for parents as service consumers the services of informational-communicative and wellness are important that are provided by the teachers of school education, though the parents not always identify themselves as the community members of education institution. Moreover, in the processes of quality management of education institutions, the parents generally take part while making suggestions and expressing their own opinions during the meetings. 